\title{
Article \\ Do Board Characteristics Matter for Growth Firms? Evidence from China
}

\author{
Qiuwei Li ${ }^{1}$, Wei Zhou ${ }^{1}$, Hui Zhou ${ }^{2, *}$ and Jiaxuan Chen ${ }^{2}$ \\ 1 School of Finance, Renmin University of China, Beijing 100872, China; liqiuwei080@sina.com (Q.L.); \\ zhouw@ruc.edu.cn (W.Z.) \\ 2 Faculty of Business and Economics, The University of Auckland, Auckland 1010, New Zealand; \\ jche437@aucklanduni.ac.nz \\ * Correspondence: h.zhou@auckland.ac.nz
}

Citation: Li, Qiuwei, Wei Zhou, Hui Zhou, and Jiaxuan Chen. 2021. Do Board Characteristics Matter for Growth Firms? Evidence from China. Journal of Risk and Financial Management 14: 380. https:// doi.org/10.3390/jrfm14080380

Academic Editor: Khaled Hussainey

Received: 18 June 2021

Accepted: 13 August 2021

Published: 17 August 2021

Publisher's Note: MDPI stays neutral with regard to jurisdictional claims in published maps and institutional affiliations.

Copyright: (c) 2021 by the authors. Licensee MDPI, Basel, Switzerland This article is an open access article distributed under the terms and conditions of the Creative Commons Attribution (CC BY) license (https:// creativecommons.org/licenses/by/ $4.0 /$ )

\begin{abstract}
Previous research on the effect of board characteristics mostly examines established firms This raises the question of whether the findings from the board characteristics literature are applicable to rapidly growing enterprises, as their corporate governance landscape can be very different from that in large, mature companies. Our paper extends the corporate governance literature by investigating the performance implications of board characteristics in startups using a unique set of firms: 121 startups operating in the information technology industry listed on the Growth Enterprise Market (GEM) in China. Using a firm performance indicator constructed through the factor analysis method, we find significant correlations between firm performance and board size, age structure, board meeting frequency, and board ownership of shares. Our findings contribute to the corporate governance literature by shedding new light on the performance implications of board characteristics for startups operating in fast-paced industries.
\end{abstract}

Keywords: corporate governance; board for startups; emerging markets

\section{Introduction}

The board of directors has ultimate authority in corporate decision making and the formation and structure of the board can have important implications for corporate governance as well as firm performance (Adams and Ferreira 2007; Adams et al. 2010; Farag et al. 2014; Mallin and Ow-Yong 2012). Previous research shows that firms have different governance requirements as they evolve through their life cycle and boards of directors for startups can take on different roles and functions than those for established firms (Ingley and van der Walt 2003; Ingley and McCaffrey 2007). While the literature has produced extensive evidence on the composition of large and mature firms, we know comparatively little about the boards of startups (Ingley and McCaffrey 2007; Ewens and Malenko 2020). This study extends the corporate governance literature by investigating the performance implications of board characteristics in startups using a unique set of firms: 121 startups operating in the information technology industry listed on the Growth Enterprise Market (GEM) in China.

Launched in 2009 as a standalone board of the Shenzhen stock exchange, GEM is designed to help promising startups that do not qualify to be listed in the main board of the exchange to raise capital in the Chinese stock market. The information technology industry accounts for almost 50\% of companies listed on GEM. We take advantage of the annual disclosure requirements for firms listed on GEM to study the performance implications of board characteristics for growth firms in high-tech industries. Our sample consists of 121 GEM-listed firms in the information technology industry from 2014 to 2017. The GEM status of our sample firms offers a unique opportunity to investigate the performance implications of boards of directors as startups go through a crucial stage of development in their life cycle when large scale, firm-level data are often unavailable. 


\section{Literature Review: Board of Directors for Startups}

While previous literature does not provide conclusive evidence on the link between board of directors and firm performance, there is a considerable body of empirical literature supporting a link between board governance effectiveness and various financial and market-based measures of organizational performance for established companies (Bøhren and Ødegaard 2006; Farag et al. 2014; Ingley and van der Walt 2003; Mallin and Ow-Yong 2012). Traditionally, agency theory and resource dependence theory are the most important theoretical foundations for articulating the roles of boards (Strenger 2004). Agency theory focuses on the conflict of interests and the need for monitoring and control. In contrast, resource dependence theory views the board of directors as a valuable resource for value maximization. These theories highlight the two essential roles of the board of directors. One is monitoring; the other is advisory. More recently, Blair and Stout (2001) were the first to propose a mediation role. They argue that board members should not be viewed as "agents" who exclusively serve the interests of shareholders, but rather as "mediators" who represent the interests of many diverse groups.

Previous literature highlights that firms have very different governance requirements as they evolve through their life cycle and thus boards of directors for startups can take on different roles and functions than those for established firms (Ewens and Malenko 2020; Ingley and van der Walt 2003; Ingley and McCaffrey 2007). "Active ownership" is the description given by Taylor (2003) of boards of directors for startup companies where owners and directors are actively engaged in the development and implementation of strategy in the business, which often involves decision making that would generally be the domain of management in an established company.

For board members for startups, the ability to attract capital and manage capital deployment is critical during the life cycle from conceptualization through to production and to marketing. Consistent with this view, a 2007 white paper by a group of Venture Capital industry experts summarizes the general duties of startup directors as "serving as fiduciaries for all shareholders; hiring, evaluating, and ring the CEO and approving officer selection; ... reviewing and confrming basic company objectives and business strategy;... approving equity incentives and establishing executive compensation; [and] overseeing regulatory and legal compliance."

\section{Research Hypotheses}

\subsection{Board Size and Firm Performance}

Corporate governance researchers have long argued that maintaining a reasonable size for the board of directors is important to firm performance. On the one hand, it has been suggested that larger boards can help obtain more corporate resources, bring in more talent/expertise to the board, and establish a more favorable corporate image. Of course, excessive expansion of board of directors can also cause problems ranging from slow decision making to free riding issues. Jensen (2000) argues that conflicts within board members can arise when the board is too large: it may not even be possible to exercise effective supervision over management when there are more than seven or eight members on the board.

There has been a long line of literature that empirically investigate the "optimal" size for boards of directors (Boone et al. 2007; Coles et al. 2008). Yermack (1996) represents one of the earliest studies of this line of research and finds a negative relationship between the number of directors on the board and Tobin's $Q$, which is the proxy for firm performance. Lipton and Lorsch (1992) and Eisenberg et al. (1998) find similar results. On the other hand, Ho and Williams (2003) find no significant relation between the number of board members and firm performance, based on their study of 105 companies in the United Kingdom and 94 companies in Sweden.

It is important to note that the evidence from the existing literature on the relationship between board size and firm performance is mostly based on large, established corporations and may not be applicable to small/young firms operating in high-tech industries. In 
particular, the advisory role of boards is likely to be more prominent than the supervisory role for fast growing IT firms operating in dynamic environments. The wider range of expertise and perspectives brought by larger board size can become important and bring significant benefits in the formulation of strategies for such firms. If this is the case, board size can have a positive effect on firm performance for growth firms. Thus, we test the following hypothesis:

Hypothesis 1. (H1). Null Form. No significant correlation exists between the number of directors on the board and firm performance.

\subsection{Board Age and Firm Performance}

Bantel and Jackson (1989) and Wiersema and Bantel (1992) argue that people of different age groups have different preferences towards risk-taking. Younger executives are likely to be less risk-averse than their older, more experienced counterparts. The risk attitudes of board members can have significant implications for strategic decisions of the firm. For small high-tech firms, higher levels of risk tolerance may be more conductive to firm performance as these firms operate in fast-paced environments and depend critically on continuous innovation to stay competitive. On the other hand, senior board members are likely to have more social resources and connections, which can help boost firm performance. Thus, we test the following hypothesis:

Hypothesis 2. (H2). Null Form. No significant correlation exists between the average age of the board of directors and firm performance.

\subsection{Meeting Frequency and Firm Performance}

The frequency of board meetings is an important indicator used by researchers as a measure for the behavioral characteristics of the board (Fich and Shivdasani 2006; Field et al. 2013). Vafeas (1999) argues that boards meeting frequently is a sign of difficult business environment and deteriorating firm performance. In contrast, Lipton and Lorsch (1992) argue that more active boards help improve decision making and accountability, thus suggesting a positive relationship between board meeting frequency and firm performance. Given the conflicting views in the literature, we empirically test the following hypothesis (null form):

Hypothesis 3. (H3). Null Form. No significant correlation exists between the number of board meetings and firm performance.

\subsection{Board Ownership and Firm Performance}

Jensen and Meckling (1976) argue that board directors holding a higher proportion of shares help align the interest of board members and shareholders, thus reducing agency cost. This can lead to better decision making and improved firm performance. On the other hand, ownership of shares may compromise the independence of board members and lead to potential conflicts of interest. Thus, we test the following hypothesis:

Hypothesis 4. (H4). Null Form. No significant correlation exists between the proportion of shares held by the members of board of directors and firm performance.

\section{Methods}

\subsection{Construction of Firm Performance Measure}

To test our hypotheses, we need to choose a dependent variable that captures the intrinsic firm performance. It is important not to use Tobin's $Q$, stock return, or other stock-price based indicators to measure firm performance because stock prices for small, young firms listed on GEM in our sample can be highly volatile (Makhija and Trivedi 2021). For our purpose, we construct a measure of firm performance using three accounting-based 
performance measures (ROA, ROE and EPS) through factor analysis. Factor analysis has the advantage of being able to identify the persistent dimensions underlying the different measures that may not be apparent from direct analysis, which helps provide a more consistent and comparable performance indicator.

The concept of factor analysis originated in the beginning of the last century, when several researchers including Charles Spearmen and Karl Pearson used it for the first time in a statistical analysis related to IQ tests. The basic method is to break down each research variable into several influencing factor variables. Eventually, each original variable becomes two groups of influencing factors, where one group contains the special factors that every variable individually has and with which the original variable cannot be explained by the factor variables, and the other group contains all of the influencing factor variables that exist commonly in all of the original variables and that are composed of a few common factors. Eventually, the reduction in order or simplification of the original variables is achieved by conversion through factor analysis. The method of factor analysis may be represented by mathematical models as follows:

$$
\begin{gathered}
\mathrm{x}_{1}^{*}=\mathrm{a}_{11} \mathrm{~F}_{1}+\mathrm{a}_{12} \mathrm{~F}_{2}+\ldots+\mathrm{a}_{1 \mathrm{~m}} \mathrm{~F}_{\mathrm{m}}+\mathrm{e}_{1} \\
\mathrm{x}_{2}{ }^{*}=\mathrm{a}_{21} \mathrm{~F}_{1}+\mathrm{a}_{22} \mathrm{~F}_{2}+\ldots+\mathrm{a}_{2 \mathrm{~m}} \mathrm{~F}_{\mathrm{m}}+\mathrm{e}_{2} \\
\ldots \\
\mathrm{x}_{\mathrm{p}}{ }^{*}=\mathrm{a}_{\mathrm{p} 1} \mathrm{~F}_{1}+\mathrm{a}_{\mathrm{p} 2} \mathrm{~F}_{2}+\ldots+\mathrm{a}_{\mathrm{pm}} \mathrm{F}_{\mathrm{m}}+\mathrm{e}_{\mathrm{p}}
\end{gathered}
$$

Here, $x^{*}$ represents the data after standardization; $F$ is the common factor; and $e_{1}$ to $e_{p}$ are the special factors, which are akin to residuals in regression analysis. In addition, $\mathrm{x}^{*}, \mathrm{~F}$, and e satisfy the following properties:

1. $E\left(x^{*}\right)=0, \operatorname{cov}(x)=1$, that is, the expected value of the variable after standardization is 0 , and the variance is 1 ;

2. $\quad \mathrm{E}(\mathrm{F})=0, \operatorname{cov}(\mathrm{F})=1$, that is, the expected value of the common factor after standardization is 0 , and the variance is 1 ;

3. $\mathrm{E}(\mathrm{e})=0, \operatorname{cov}(\mathrm{e})=0, \operatorname{cov}\left(\mathrm{e}_{\mathrm{i}}, \mathrm{F}\right)=0$, that is, the expected value of the special factor after standardization is 0 , the variance is 0 , and the special factor is not related to the principal component factor.

The specific process of standardization of the financial data is shown as follows:

$$
X_{p}^{*}=\frac{X_{p i}-\overline{X_{i}}}{S_{i}}
$$

Here, $S_{i}$ is the variance of the $i$-th variable, and $\overline{X_{i}}$ is the mean value of the $i$-th variable. $X_{p i}$ is the original value, and $X_{p}^{*}$ is the value of the variable after standardization. Since the three chosen indicators are all positive indicators, there is no problem of converting moderate indicators into positive indicators.

The results of the KMO test show that a statistic after standardization is $0.710 .{ }^{1}$ This indicates that the indicators are suitable for factor analysis. We also see that results of the Bartlett's test of sphericity has a significance of 0.000 , that is, less than 0.05 , which further shows that common factors exist among the three chosen performance indicators, thus making them suitable for factor analysis.

In our results, the eigenvalue of one factor is greater than 1 , indicating that only one factor should be extracted. The cumulative variance contribution corresponding to this component is $77.73 \%$, thus the first factor can explain the main content. It is not possible to rotate this solution as only one factor is extracted. Finally, the factor score construction is shown below.

The common factor $\mathrm{F} 1=0.368 \mathrm{ROA}+0.369 \mathrm{EPS}+0.397 \mathrm{ROE}$.

Thus, the performance indicator based on factor analysis (PFI) is constructed as:

$$
\mathrm{PFI}=77.73 \% \times \mathrm{F} 1=0.286 \mathrm{ROA}+0.287 \mathrm{EPS}+0.309 \mathrm{ROE}
$$


We standardize the PFI so that the mean of the variable converts to zero. If a company's PFI is greater than zero, it means that the company's performance is higher than the average standard scores of all companies. If PFI is negative, it means that the firm performance is below average. The higher the PFI, the better the company's performance. We use the PFI as the dependent variable throughout our empirical analyses in this study.

\subsection{Independent Variables}

To test our hypotheses, we regress the firm performance measure constructed in the last section on our explanatory variables. Table 1 provides summary of variables in our empirical analyses.

Table 1. Variables description.

\begin{tabular}{cc}
\hline Variables & Description \\
\hline Dependent Variables & PFI (Performance indicators) calculated by using ROA, ROE and EPS \\
\hline PFI & $\begin{array}{c}\text { Number of directors on the board } \\
\text { Test Variables }\end{array}$ \\
\hline BOARDSIZE & $\begin{array}{c}\text { Number of board meetings held yearly } \\
\text { AGE }\end{array}$ \\
MEETING & Sum of shares held by board members \\
\hline HOLDING & Company's listing period \\
Control Variable & Total assets \\
TIMEFROMIPO & Leverage ratio measured as asset to liability ratio \\
AST &
\end{tabular}

We also include the following control variables in all regressions:

Period of listing (TIMEFROMIPO). Companies tend to perform better in the year of being listed and in the few years prior to it. This is because of strong incentives for startups to meet the listing targets and stricter supervision during the initial period of listing. Moreover, young firms face a fast-changing business landscape and likely adopt business strategies that are different from those of more established and mature companies. Thus, we include period of listing (YEAR) as a control variable.

Total assets (AST). In general, the larger the company, the larger and more complex its management organization, which in turn leads to higher management costs such as agency and supervision costs, and a higher probability for various conflicts and contradictions to arise. At the same time, however, the larger size of the company can bring about economies of scale. In addition, the size of assets reflects the company's ability to control and use the company's assets, which in turn affects the company's ability to seize market opportunities. Therefore, the impact of the size of the company on corporate performance must not be neglected. Thus, we include total assets (AST) as a control variable in our empirical analyses.

Leverage ratio (LVR). Previous research provides some evidence that debt financing can help enhance firm performance by improving corporate governance. Jiang and Huang (2011) use Chinese data to show that, in addition to providing cash flows, debt financing can play a disciplinary role in curbing managerial opportunistic behavior. Thus, we include leverage ratio (LVR) measured as asset to liability ratio as a control variable in our empirical analyses.

\subsection{Sample Description}

Table 2 provides the summary statistics for our sample firms. As reported in Table 2, the average board in our sample has seven to eight members. The average age of board members is around 50 years old. On average, the board of directors meets 10 times annually. The average board in our sample holds $33 \%$ of company shares. 
Table 2. Summary statistics.

\begin{tabular}{|c|c|c|c|c|c|}
\hline Variable & Obs & Mean & Std. Dev. & Min & Max \\
\hline BOARDSIZE & 456 & 7.7193 & 1.6628 & 4 & 15 \\
\hline MEETING & 456 & 10.3978 & 3.9953 & 2 & 27 \\
\hline AGE & 456 & 49.9292 & 3.4084 & 40.11 & 60.75 \\
\hline HOLDING & 456 & 0.3347 & 0.1762 & 0 & 0.8908 \\
\hline AST & 456 & 25.0070 & 29.6182 & 2.96 & 357.22 \\
\hline LVR & 456 & 0.3473 & 0.8871 & 0.034 & 14.28 \\
\hline TIMEFROMIPO & 456 & 5.0132 & 2.0510 & 0 & 9 \\
\hline ROA & 456 & 0.0517 & 0.0572 & -0.1649 & 0.7013 \\
\hline EPS & 456 & 0.3146 & 0.4115 & -2.12 & 4.58 \\
\hline ROE & 456 & 0.0832 & 0.0887 & -0.7001 & 0.5629 \\
\hline PIF & 456 & 0.1307 & 0.1496 & -0.7083 & 1.5399 \\
\hline
\end{tabular}

\section{Results}

\subsection{Number of Board Members and Firm Performance}

We test H1 using the following regression model:

$$
\mathrm{PFI}_{i}=\alpha_{i}+\beta_{1} \text { BOARDSIZE }_{i}+\beta_{2} \text { TIMEFROMIPO } i+\beta_{3} \text { AST }_{i}+\beta_{4} L V R_{i}+\varepsilon_{i}
$$

$\mathrm{PFI}_{i}$ is the performance measure for the company constructed based on factor analysis as described in Section 3. BOARDSIZE $E_{i}$ represents the number of board members. TIMEFROMIOP, $A S T$, and $L V R$ are the control variables described in Section 4.

Table 3 provides the summary of the hypothesis testing results. As reported in the row for testing of $\mathrm{H} 1$ in Table 3, the coefficient on board size in Equation (1) is positive and statistically significant, thus rejecting $\mathrm{H} 1$ in the null form. The results indicate that board size is positively related with firm performance for growth firms. Our finding suggests that the benefits of diversity in perspectives and expertise outweigh the potential free riding and coordination problems brought about by larger boards for young, growth firms. The evidence is consistent with the view that growth firms need the board of directors to play more of an advisory role in addition to the supervisory role than mature firms.

Table 3. Summary of hypothesis testing results.

\begin{tabular}{ccccccc}
\hline Hypothesis & Equation & Explanatory Variable & Coefficient & Std Dev & $\boldsymbol{t}$ Value & $\boldsymbol{p}$ Value \\
\hline H1 & $(1)$ & BOARDSIZE & 0.008 & 0.004 & 1.927 & 0.055 \\
H2 & $(2)$ & AGE & -0.005 & 0.002 & -2.450 & 0.015 \\
H3 & $(3)$ & MEETING & 0.003 & 0.002 & 1.737 & 0.083 \\
H4 & $(4)$ & HOLDING & 0.002 & 0.000 & 3.870 & 0.000 \\
\hline
\end{tabular}

\subsection{Mean Age of Board Members and Firm Performance}

We test $\mathrm{H} 2$ using the following regression model:

$$
\mathrm{PFI}_{i}=\alpha_{i}+\beta_{1} A G E_{i}+\beta_{2} \text { TIMEFROMIPO }_{i}+\beta_{3} A S T_{i}+\beta_{4} L V R_{i}+\varepsilon_{i}
$$

$A G E_{i}$ represents the mean age of the company's board members.

The row for $\mathrm{H} 2$ in Table 3 reports the results for the regression analysis based on Equation (2). The coefficient on the average age of board members is negative and statistically significant, indicating that younger boards of directors are associated with better firm performance. This finding suggests that the demographic makeup of the "optimal' board of directors for growth firms may be very different from that documented in previous research, which focuses on established firms. 


\subsection{Number of Yearly Board Meetings and Firm Performance}

We test $\mathrm{H} 3$ using the following regression model:

$$
\text { PFI }_{i}=\alpha_{i}+\beta_{1} \text { MEETING } i+\beta_{2} \text { TIMEFROMIPO }_{i}+\beta_{3} A S T_{i}+\beta_{4} L V R_{i}+\varepsilon_{i}
$$

MEETING $i$ represents the number of board meetings held every year by the company.

The row for $\mathrm{H} 3$ in Table 3 reports the empirical results for the regression analysis based on Equation (3). The coefficient on the number of board meetings is positive and statistically significant. This shows that board meetings in our sample firms listed on GEM are not only for compliance formalities. Due to the fast-moving environment faced by growth enterprises in high-tech industries, frequent board meetings may bring substantial benefits by helping form timely strategies in response to changing market conditions and identify/resolve any emerging problems. Thus, frequent board meetings can be particularly important to growth firms.

\subsection{Proportion of Shares Held by Board Members and Firm Performance}

We test $\mathrm{H} 4$ using the following regression model:

$$
P F I_{i}=\alpha_{i}+\beta_{1} \text {HOLDING }_{i}+\beta_{2} \text { TIMEFROMIPO }_{i}+\beta_{3} A S T_{i}+\beta_{4} L V R_{i}+\varepsilon_{i}
$$

$H_{O L D I N G_{i}}$ represents the proportion of total shares held by the company's board members.

The row for $\mathrm{H} 4$ in Table 3 reports the empirical results for the regression analysis based on Equation (4). The coefficient on the proportion of shares held by board members is positive and statistically significant. This indicates that having board members hold more shares helps reduce agency costs and improve firm performance for growth firms. Stock-based compensation can be particularly important for young firms operating in high-tech industries, as these firms may not be able to pay compensation competitive with established firms.

\section{Discussion}

Fried and Ganor (2006) argue that "startup boards, unlike public company boards are frequently and intimately involved in strategic decision making and personnel issues." The GEM-listed status of our samples represents a crucial stage of development for startups as their boards face the increasing challenge of balancing the two fundamental roles: encouraging entrepreneurship and monitoring the controlling shareholders. Overall, our results are consistent with the "active ownership" view of boards of directors for startup companies (Ingley and McCaffrey 2007; Taylor 2003). The active ownership view focuses on directors as a resource pool in the business and their active role in the development and implementation of strategy, which often involves decision making that would generally be the domain of management in an established company.

First, we show a positive relationship between board size and firm performance, suggesting that the wider range of expertise and perspectives brought by larger board size can bring significant benefits in the formulation of strategies for startups. Second, our results show that startups with younger boards tend to perform better, which is consistent with findings from recent studies on the relationship between the age of board members and growth prospect (Waelchli and Zeller 2013). Third, the documented positive relationship between board meeting frequency and firm performance suggests that regular board meetings are important to the efficiency of the board to properly perform its functions. This finding is consistent with evidence from recent empirical research using data from other emerging economies (Ntim and Osei 2011). Finally, our results indicate that board directors holding a higher proportion of shares is associated with improved firm performance, echoing previous research that document a positive effect of venture capital ownership on corporate governance effectiveness (Farag et al. 2014). 


\section{Conclusions}

We investigate the effect of board characteristics on firm performance using a unique set of firms: 121 startups operating in the information technology industry listed on the Growth Enterprise Market (GEM) in China. We find that firms tend to perform better when (1) the size of the board is larger, (2) the directors on the board are younger, (3) the board members meet more frequently, and (4) the directors hold larger shares of company stocks. Our findings contribute to the corporate governance literature by shedding new light on the performance implications of board characteristics for startups operating in fast-paced industries.

It is important to interpret the findings of this study in light of its limitations. While our data offer a unique opportunity to investigate the performance implications of boards of directors as these firms go through a crucial stage of development in their life cycle, our findings may not be generalized to other jurisdictions and other industries. Moreover, we acknowledge that our research, as with all association studies, has limited ability to generate causal inferences. Future research can use samples from different socio-economic contexts and consider longitudinal studies to better explore roles of boards of directors in startups.

Author Contributions: Conceptualization, Q.L. and W.Z.; methodology, Q.L.; formal analysis, Q.L. and J.C.; data curation, Q.L.; writing — original draft preparation, H.Z.; writing —review and editing, H.Z. All authors have read and agreed to the published version of the manuscript.

Funding: This research received no external funding.

Institutional Review Board Statement: Not applicable.

Data Availability Statement: Publicly available datasets were analyzed in this study. This data can be found here: http://stock.10jqka.com.cn/chuangye/. The data collection was conducted in late 2018.

Conflicts of Interest: The authors declare no conflict of interest.

\section{Note}

If the value falls within the range of $(0.8,0.9)$, this indicates suitability for factor analysis. A value within the range of $(0.7,0.8)$ indicates general suitability. A value within the range of $(0.6,0.7)$ indicates that the indicator is not very suitable for factor analysis. A value falling below 0.5 indicates unsuitability for factor analysis.

\section{References}

Adams, Renée B., and Daniel Ferreira. 2007. A theory of friendly boards. The Journal of Finance 62: 217-50. [CrossRef]

Adams, Renée B., Benjamin E. Hermalin, and Michael S. Weisbach. 2010. The Role of boards of directors in corporate governance: A conceptual framework and survey. Journal of Economic Literature 48: 58-107. [CrossRef]

Bantel, Karen A., and Susan E. Jackson. 1989. Top management and innovation in banking: Does the composition of the top team make a different. Strategic Management Journal 10: 107-24. [CrossRef]

Blair, Margaret M., and Lynn A. Stout. 2001. Trust, Trustworthiness, and the Behavioral Foundations of Corporate Law. University of Pennsylvania Law Review 149: 1735-810. [CrossRef]

Bøhren, Øyvind, and Bernt Arne Ødegaard. 2006. Governance and performance revisited. In International Corporate Governance after Sarbanes-Oxley. Wiley: Available online: https:/ / papers.ssrn.com/sol3/papers.cfm?abstract_id=2257768 (accessed on 18 May 2021).

Boone, Audra L., Laura Casares Field, Jonathan M. Karpoff, and Charu G. Raheja. 2007. The determinants of corporate board size and composition: An empirical analysis. Journal of Financial Economics 85: 66-101. [CrossRef]

Coles, Jeffrey L., Naveen D. Daniel, and Lalitha Naveen. 2008. Boards: Does one size fit all? Journal of Financial Economics 87: 329-56. [CrossRef]

Eisenberg, Theodore, Stefan Sundgren, and Martin T. 1998. Larger board size and decreasing firm value in small firms. Journal of Financial Economics 48: 35-54. [CrossRef]

Ewens, Michael, and Nadya Malenko. 2020. Board Dynamics over the Startup Life Cycle. No. w27769. Cambridge: National Bureau of Economic Research.

Farag, Hisham, Chris Mallin, and Kean Ow-Yong. 2014. Governance, ownership structure, and performance of entrepreneurial IPOs in AIM companies. Corporate Governance: An International Review 22: 100-15. [CrossRef]

Fich, Eliezer M., and Anil Shivdasani. 2006. Are busy boards effective monitors? Journal of Finance 61: 689-724. [CrossRef] 
Field, Laura, Michelle Lowry, and Anahit Mkrtchyan. 2013. Are busy boards detrimental? Journal of Financial Economics 109: 63-82. [CrossRef]

Fried, Jesse M., and Mira Ganor. 2006. Agency Costs of Venture Capitalist Control in Startups. New York University Law Review 81: 967-1025.

Ho, Carol-Anne, and S. Mitchell Williams. 2003. International comparative analysis of the association between board structure and the efficiency of value added by a firm from its physical capital and intellectual capital resources. International Journal of Accounting 38: 465-91. [CrossRef]

Ingley, Coral B., and Kevin McCaffrey. 2007. Effective governance for start-up companies: Regarding the board as a strategic resource. International Journal of Business Governance and Ethics 3: 308-29. [CrossRef]

Ingley, Coral B., and Nicholas T. van der Walt. 2003. Board configuration: Building better boards. Corporate Governance: The International Journal of Effective Board Performance 3: 5-17. [CrossRef]

Jensen, Michael C. 2000. A Theory of the Firm: Governance, Residual Claims, and Organizational Forms. Harvard: Harvard University Press.

Jensen, Michael C., and William H. Meckling. 1976. Theory of the firm: Managerial behavior, agency costs and ownership structure. Journal of Financial Economics 3: 305-60. [CrossRef]

Jiang, Fuxiu, and Jicheng Huang. 2011. Managerial Incentive, Debt, and Firm Value. Economics Research 5: 46-60. (In Chinese).

Lipton, Martin, and Jay W. Lorsch. 1992. A modest proposal for improved corporate governance. Business Lawyer 48: 59-77.

Makhija, Harnesh, and Pankaj Trivedi. 2021. An empirical investigation of the relationship between TSR, value-based and accountingbased performance measures. International Journal of Productivity and Performance Management 70: 1118-36. [CrossRef]

Mallin, Chris, and Kean Ow-Yong. 2012. Factors influencing corporate governance disclosures: Evidence from Alternative Investment Market (AIM) companies in the UK. The European Journal of Finance 18: 515-33. [CrossRef]

Ntim, Collins G., and Kofi A. Osei. 2011. The impact of corporate board meetings on corporate performance in South Africa. African Review of Economics and Finance 2: 83-103.

Strenger, Christian. 2004. The corporate governance scorecard: A tool for the implementation of corporate governance. Corporate Governance 12: 11-15. [CrossRef]

Taylor, Bernard. 2003. Board leadership: Balancing entrepreneurship and strategy with accountability and control. Corporate Governance: An International Review 3: 3-5. [CrossRef]

Vafeas, Nikos. 1999. Board Meeting Frequency and Firm Performance. Journal of Financial Economies 53: 113-142. [CrossRef]

Waelchli, Urs, and Jonas Zeller. 2013. Old captains at the helm: Chairman age and firm performance. Journal of Banking E Finance 37: 1612-28.

Wiersema, Margarethe F., and Karen A. Bantel. 1992. Top management team demography and corporate strategic change. Academy of Management Journal 35: 91-121.

Yermack, David. 1996. Higher marker valuation of companies with a small board of directors. Journal of Financial Economics 40: 185-212. [CrossRef] 